\title{
Fault/no fault, part 3: vested interests and the silence of suffering patients cited as obstacles to system change
}

$\mathrm{J}$ ames Kreppner was a 24-year-old Toronto law student when in 1985, he was infected with HIV through blood products. Seven years later, he issued a formal notice against the provincial Crown, indicating he would be launching a lawsuit for damages. But when the multi-provincial/ territorial assistance program was announced in the fall of 1993, Kreppner took the settlement, as did the vast majority of others with hemophilia who contracted HIV through blood products. "It was important to get help quickly, without a lot of hassle and roadblocks," he explains.

Given his experience, it's not too surprising that Kreppner now favours the introduction of a permanent nofault compensation scheme for those who have suffered medical injury.

The federal and provincial compensation plans that were introduced in the wake of Canada's tainted blood scandal are one example of the ad hoc no-fault programs that have sprung up, usually in response to a crisis (see sidebar, page 516).

But Canada's overall medical liability system has proved resilient to significant change.

For a couple of years, the Canadian Medical Protective Association, which insures $95 \%$ of Canadian doctors, took to producing reports that considered nofault compensation schemes: the 2005 reports Towards the right balance and Alternative Patient Compensation Models in Canada and the 2006 International medical liability systems - A comparative view. But the 2006 report's sequel, which promised to examine the results if "alternatives" were applied to the Canadian context, was never produced. And no-fault compensation for medical injury has not even been explored in a pilot project - that favoured Canadian approach to testing out new approaches. The lack of activity in Canada contrasts with what is taking

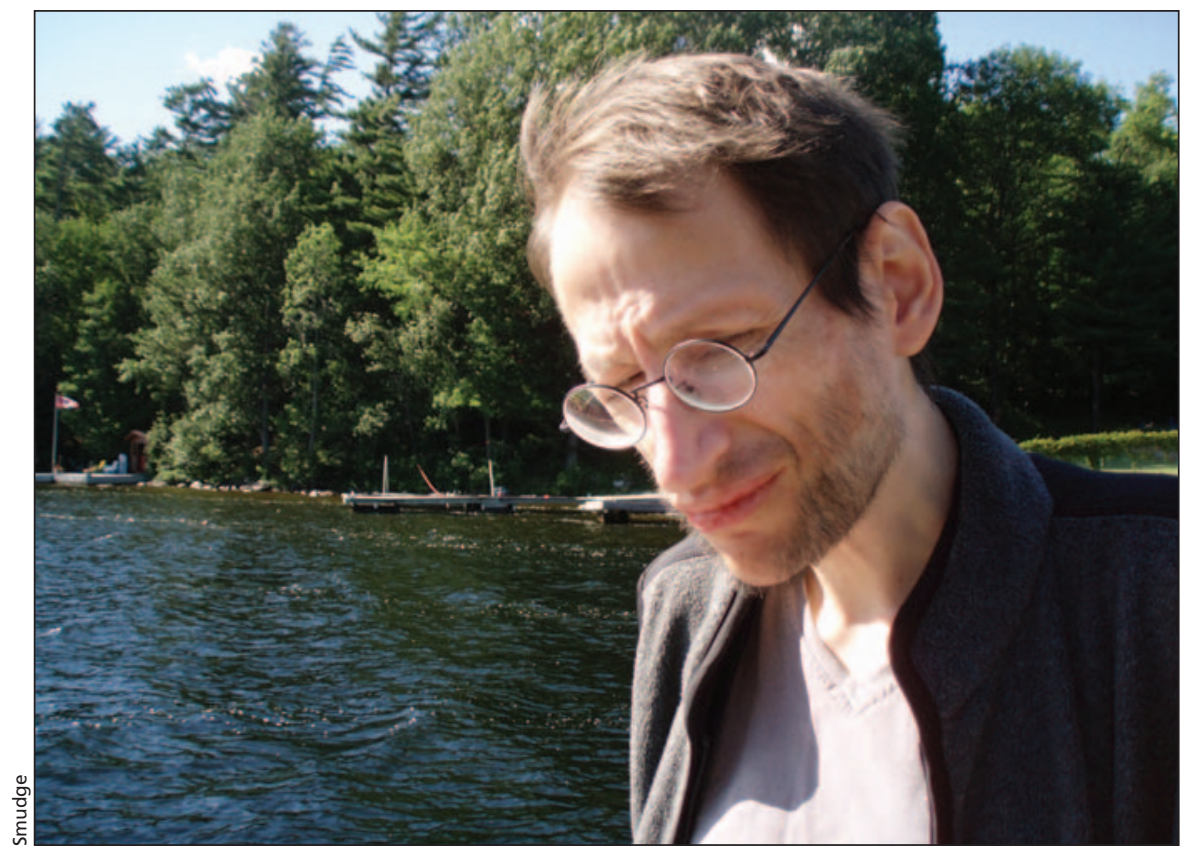

Lawyer James Kreppner gets "kind of angry" at the argument that a no-fault compensation scheme for medical injury would be too expensive. "Somebody has to remind government about why it exists," he argues.

place in many other countries that have begun experimenting with no-fault plans (CMAJ 2008;179[4]:309-11).

Pressure to create a permanent scheme appears to be at a low ebb. Some argue this is because the current system works quite well for all parties. And according to the Canadian Medical Protective Association, the current medical liability system "is fundamentally sound and is very likely the best possible model for our circumstances."

Others, however, say the lack of change is due to the weight of vested interests in the legal and insurance communities, the issue's lack of public visibility, and the isolation of injured patients who lack a lobbying presence and are often constrained from discussing their circumstances.

"Most people who have gone down the often lengthy road of complications, or have lost a loved one, are too emotionally, financially, physically and socially drained to make a fuss," says Wendy Armstrong, an Edmonton, Alberta-based Consumers Association of Canada spokesperson. For those few who do launch lawsuits, and settle out of court, keeping details of the settlement confidential is usually a condition of the agreement. That imposed silence serves to reinforce the already low profile of the compensation issue, Armstrong says.

"Victims without voices," comments Robert Prichard, "is no evidence of a system 'that works quite well'." Prichard, now chief executive officer of Torstar Corporation, wrote the 1990 report, Liability and Compensation in Health Care report, for the nation's deputy ministers of health.

The Canada Health Act provides a partial no-fault system, since provincial health care plans typically cover the costs of treatment for patients who have suffered medical injuries, says 
Armstrong. However, injured patients' financial circumstances are deteriorating. One reason for this, she says, is the trend toward shorter hospitals stays which means discharged patients must in his 1997 Royal Commission of Inquiry on the Blood System in Canada report. After detailing the appallingly lengthy and expensive legal procedures that one family endured while seeking

\section{"Not in my lifetime; maybe not in yours. But it will come." - Horace Krever on no-fault compensation}

bear the costs of prescription drugs and at-home health services that invariably are needed. Another reason is the changing employment market in which fewer people have jobs with disability or income replacement benefits, she adds.

"The compassion of a society can be judged by the measures it takes to reduce the impact of tragedy on its members," Mr. Justice Horace Krever wrote redress in the courts after a blood transfusion left both parents dead from AIDS-related illnesses, Krever recommended that, "without delay," the provinces and territories devise permanent no-fault schemes for compensating persons who suffer serious adverse consequences from the administration of blood or blood products. The recommendation has not been acted upon.

In his report, Krever illustrated the "formidable task" of proving fault in medical cases by drawing on his experience presiding over a 1983 case where a previously healthy man became quadriplegic after undergoing an angiogram. His lawsuit was dismissed because he could not prove that his medical care had been negligent. "I confess to a feeling of discomfort over a state of affairs ... in which a patient, who undergoes a necessary procedure ... is not entitled to be compensated because of the absence of fault on the part of those involved in his care," Krever wrote in his judgment.

In fact, very few patients even take a case to trial and only a small percentage of those who do are successful. "Lawsuits are slow, complex, costly despite the greater availability of contingency fees, unpredictable and in the case of medical liability claims, usually unsuccessful," states Osgoode Hall law professor Joan Gilmour in her 2006 report Patient Safety, Medical Error and Tort Law: An International Comparison. The

\section{No-fault schemes usually a response to high-profile tragedies}

High-profile tragedies have been the catalysts for almost all of the no-fault compensation plans that have emerged in Canada. "One-off compensation programs have been introduced when there is a big disaster and public outcry and the political will to do something," says Douglas Elliott, a Toronto lawyer with experience in malpractice litigation.

The best-known examples are the government assistance programs created during the 1990s in the wake of the tainted blood scandals, in which Canadians became infected with HIV and hepatitis $C$ as a result of receiving blood transfusions and blood products.

More recently, a plan was established for the victims of Canada's worst-ever Escherichia coli tragedy, in Walkerton, Ontario, which left 7 people dead and hundreds ill.

In contrast, a Quebec compensation plan for those injured as a result of a vaccination was inspired by a single court case: after being vaccinated against measles as part of a government-sponsored program, 5-year-old Nathalie Lapierre developed acute viral encephalitis that resulted in permanent, total disablement.

Her parents took their lawsuit all the way to the Supreme Court of Canada, but their case was dismissed in 1985 because fault could not be proved. (Under both common law and Quebec's civil law system, claimants for damages must prove negligence to be entitled to compensation.)
Later that year, Quebec introduced legislation to provide compensation, without proof of fault, for injuries causally related to vaccination. Other provinces have not followed suit, although periodically, there have been calls for a Canada-wide vaccine-related injury compensation scheme. The Canadian Pediatric Society endorsed the idea in 1986, as did a recent CMAJ editorial (CMAJ 2007;176(12):168). But, like calls for a universal no-fault compensation program for medical injury, these have gone unheeded.

The only no-fault scheme endorsed in principle by the Canadian Medical Protective Association is one for infants who have suffered birth-related neurological injuries. The purpose of such a plan would be "to reduce the 'lottery effect' resulting from the difficulty of finding fault in these cases and to take a controversial component out of the present system," states a 2005 report. A separate compensation system for compromised infants poses some potential advantages, the most "appealing" of which might be "a greater degree of societal equity, particularly in many of the circumstances where cause for fault is difficult to determine," states another association report. It seems to have escaped the authors of the reports that the rationale for this limited no-fault compensation for infants could be applied more widely to others who suffer medical harm. 
Canadian Medical Protective Association reports that of the 577 legal actions against physicians that went to trial from 2002 to 2006, plaintiffs were successful only $21 \%$ of the time (in 122 cases). During that period, the annual number of legal actions that were dismissed, discontinued or abandoned ranged between 664 and 848, while the number of annual settlements ranged from 43 to 49 .

Today, Krever is convinced that the introduction of a nofault system for all medical injury (not just blood-related injury) is inevitable. "Not in my lifetime; maybe not in yours," he says. "But it will come." He says arguments against such a system are similar to those used when workers' compensation schemes were introduced. But, Krever observes, "no one is clamouring for a return to tort for workrelated injuries."

"Tort is clearly inadequate to compensate everyone who is injured through error," says Elaine Gibson, associate director of the Health Law Institute at Dalhousie University in Halifax, Nova Scotia. "It does poorly, and does particularly poorly in medical malpractice,"

she says, owing in part to the "vigorous defence policies" of the Canadian Medical Protective Association. In contrast, she says, no-fault compensation works better to compensate more broadly, but this means claimants usually get substantially lower amounts than they would if successful in a lawsuit.

Those who want to see Canada adopt a no-fault system for medical harm are divided over whether tort should be retained as a "safety valve" option alongside a no-fault system, or abandoned completely. Krever, for example, argues that maintaining the tort option of launching a lawsuit would invite a 2-tier system: only those who could afford it would go to court.

Others, including Gibson and Kreppner, argue for retaining the tort option. "The benefit of retaining tort would be that it puts pressure on the

system to keep no-fault awards at a reasonable level," says Kreppner. "It is not an imaginary fear that otherwise, awards would face downward pressure

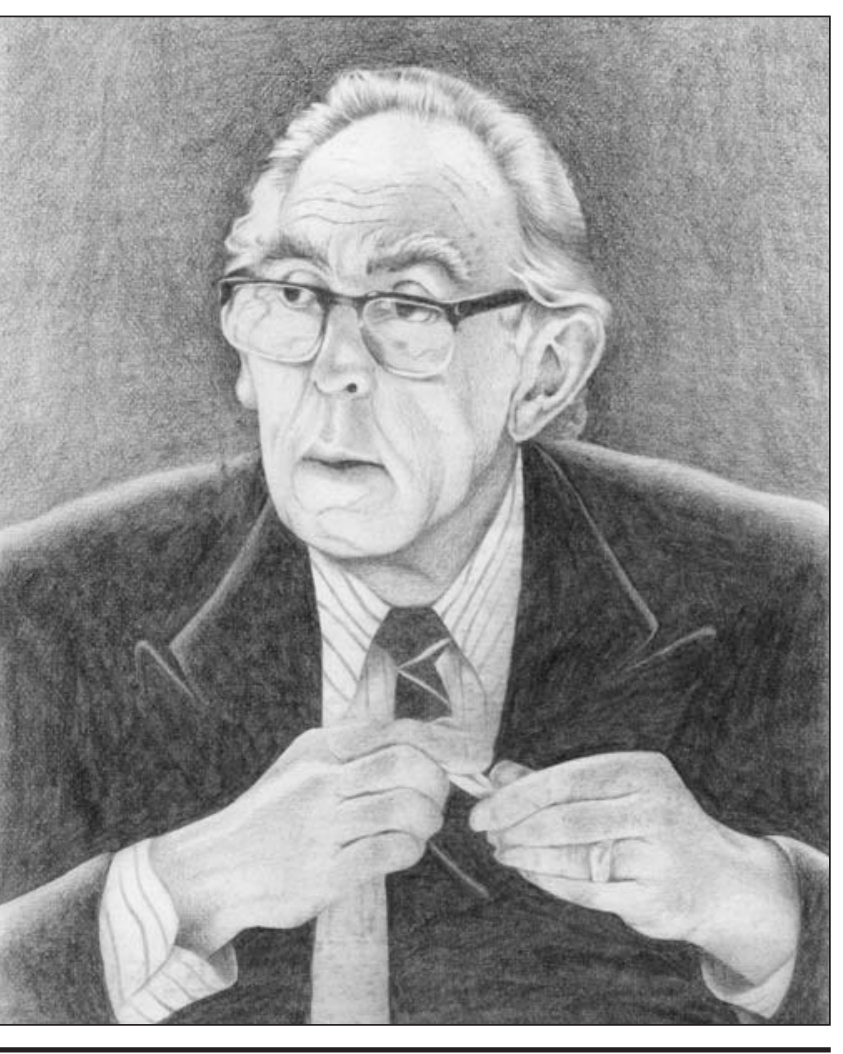

In his report on Canada's tainted blood disaster, Mr. Justice Horace Krever wrote that "the compassion of a society can be judged by the measures it takes to reduce the impact of tragedy on its members." disagreement," Gilmour observed in her report.

The Canadian Medical Protective Association estimated there would be an annual $\$ 2.6$ billion tab for a no-fault system to compensate "unintended and avoidable" injuries. Its report concluded that monies should instead be funnelled into patient safety and tort reform.

But Prichard wrote that "the goal of social justice" requires more than legislative reform and patient safety improvements. "We would continue to leave most people who suffer medical injuries without meaningful recourse, leaving them to bear their own losses except to the extent that they have private disability insurance or other sources of support. ... It is simply not good enough to ignore the vast majority of these victims."

Adds Krever: "Economics is not my field; I am thinking of social justice. But no system could be more expensive than the current one. I don't see how it could be."

James Kreppner becomes notably animated when asked about cost as an obstacle to
- we've seen that in other countries."

The advent of contingency fee arrangements, under which lawyers take a percentage of successful awards, means patients don't need to be well off to launch lawsuits, he adds. Without the pressure of the tort option, recipients of no-fault payouts could be "given small amounts, and that is not justice, either," he says.

Prichard, in his 1990 report, also recommended that tort be retained as an option. And that, say some, is why his report went nowhere - suggesting that Prichard was unrealistic if he expected any Canadian government to take on the costs of no fault alongside the tort option.

Does it then come down entirely to money?

"The projected costs of a broad nofault system give rise to the greatest establishing a no-fault compensation scheme. "Somebody has to remind government about why it exists. It is not there to deprive people of their just rights ... it is there to serve, to make sure people live in a good place with protection. Whenever someone throws a financial argument like that at me, I get kind of angry. We waste so much money in this country - why don't we want to spend it on protecting people?" — Ann Silversides, CMAJ

DOI:10.1503/cmaj.081201

This is the final part of a 3-part series exploring no-fault insurance options (CMAJ 2008;179[4]:309-11 and 179[5]:1-3). Related earlier articles examined complaints and compensation (CMAJ 2008;178[1]:14-6, CMAJ 2008;178[6]:671-3 and CMAJ 2008; 178[11]:1409-11). 